\title{
Communication Patterns of Islamic Religious Education Teachers and Parents in the Covid-19 Pandemic
}

\author{
Ali Akbarjono ${ }^{1}$, Nina Siti Salmaniah Siregar ${ }^{2}$, Erniwati La Abute ${ }^{3}$, Ahmad \\ Zainuri 4
}

DOI: $10.35445 /$ alishlah.v13i3.1495

Article Info

Keywords:

Communication Pattern,

Teachers, Parents, Communication Media

Kata kunci:

Pola Komunikasi, Guru, Orang Tua, Media

Komunikasi

\section{Abstract}

Islamic Religious Education teachers need to establish harmonious relationships with parents and students during the Covid-19 Pandemic even though students study from home, so communication between teachers and parents is required to supervise their children's learning at home. This study aims to analyze the communication patterns used by Islamic Religious Education teachers and parents during the Covid-19 Pandemic and the supporting and inhibiting factors in Junior High Schools. The research method used is descriptive qualitative with a phenomenological approach. Data were collected through in-depth interviews with structured interview techniques. Tool for organizing data with Thematic Analysis. Then the data were analyzed by the Colaizzi method. This study concludes that the communication pattern used by Islamic Religious Education teachers and parents is a secondary or twoway communication pattern. Harmonious communication between teachers and parents supports student and teacher learning success. Thus, the communication needs to be carried out intensely and continuously and involves other school members such as school principals, homeroom teachers, and students.

\begin{abstract}
Abstrak
Guru Pendidikan Agama Islam perlu menjalin hubungan yang harmonis dengan orang tua dan peserta didik di masa Pandemi Covid-19 meskipun peserta didik belajar dari rumah sehingga diperlukan komunikasi antaraguru dengan orang tua untuk mengawasi pembelajaran anaknya di rumah. Penelitian ini bertujuan untuk menganalisis pola komunikasi yang digunakan guru Pendidikan Agama Islam dan orang tua selama masa Pandemi Covid-19 serta faktor pendukung dan penghambatnya di Sekolah Menengah Pertama. Metode penelitian yang digunakan adalah kualitatif deskriptif dengan pendekatan fenomenologi. Data dikumpulkan melalui wawancara mendalam dengan teknik wawancara terstruktur. Alat untuk mengorganisir data dengan Thematic Analysis. Kemudian data dianalisis dengan metode Colaizzi. Penelitian ini menyimpulkan bahwa pola komunikasi yang digunakan guru Pendidikan Agama Islam dan orang tua adalah pola komunikasi sekunder atau dua arah.
\end{abstract}

\footnotetext{
${ }^{1}$ IAIN Bengkulu, Indonesia

Email: aliakbarjono@iainbengkulu.ac.id

${ }^{2}$ Universitas Medan Area, Indonesia

Email: ninasitisalmaniah@staff.uma.ac.id

${ }^{3}$ Universitas Muhammadiyah Luwuk Banggai, Indonesia

Email: ernywaty30@gmail.com

${ }^{4}$ UIN Raden Fatah Palembang, Indonesia

Email: ahmadzainuri_uin@radenfatah.ac.id
} 
Komunikasi yang harmonis antara guru dan orang tua menjadi faktor pendukung keberhasilan pembelajaran siswa dan guru. Dengan demikian komunikasi tersebut perlu dilakukan secara intens dan berkesinambungan serta melibatkan warga sekolah lainnya seperti kepala sekolah, wali kelas, dan siswa.

\section{INTRODUCTION}

Communication is necessary for every human being to maintain survival (Masdul, 2018; Sihotang, 2014; Syatriadin, 2018). Humans can interact with humans and fulfill their lives (Tatang, 2016). Communication is an essential human activity as social beings who need each other. The importance of this communication is implied in the letter Ar-Rahman verses 1-4 that Allah teaches humans to be good at speaking (communicating) (Kurniawati, 2013). Likewise, teachers need to communicate between teachers, students, and parents during and outside of learning.

Interpersonal communication is an obligation to establish a harmonious relationship between teachers and students. At the time of learning activities, practical or not, very much depends on the communication between the two. But because the teacher is the holder of class control, the responsibility for good, healthy, and effective communication lies with the teacher. The effectiveness of communication can be seen if the messages conveyed, such as teaching materials, can be accepted and understood and give rise to positive feedback (Masdul, 2018). Learning communication is essential for teachers.

The ability of teachers to communicate is part of the competencies required by Law Number 14 of 2005 concerning Teachers and Lecturers that must be possessed and mastered. The law mandates that teachers have social competence (Penyusun, 2005). Teachers as learning agents must have academic qualifications from accredited universities (S1/D4) and have four personalities, professional, pedagogic, and social competencies. One of them is social competence, namely the ability of educators as part of the community to communicate and get along with students, fellow educators, education staff, parents/guardians of students, and the surrounding community (Ashsiddiqi, 2012; Trisno, 2010). The social competence of the teacher will have an impact on the effectiveness of learning with practical, polite, and empathetic communication (Muspiroh, 2016).

Communication between teachers and parents using short message applications such as WhatsApp plays an essential role in supporting the success of the learning process, especially during the Covid-19 pandemic, which has not yet shown when it will end. The current presence of Covid-19 has an impact on the education sector by shifting face-to-face learning in the classroom to online learning (W. A. F. Dewi, 2020). All activities are carried out online, such as material delivery, assessment, assignment assignments, including communication with parents (Maryani, 2020; Risdoyok \& Aprison, 2021; Sun'iyah, 2020).

Islamic religious education (PAI) teachers during the Covid-19 Pandemic began to adapt by carrying out online learning through various applications according to learning needs such as Google Classroom, Google Meet, Zoom, WhatsApp, and others. (Zaini et al., 2021). This application is used to make learning activities at school successful. Covid-19 reminds stakeholders that there is a need for good cooperation and communication between teachers and parents. Thus the importance of collaboration between teachers and parents. The teacher as a facilitator must provide convenience for students to learn various things around them (Sopian, 2016). Meanwhile, parents must support their children's learning activities at home. Therefore, communication between teachers and parents must remain in synergy in placing their students' education in the current new normal conditions. So that collaboration occurs between teachers and parents in supporting education for students (Astuti \& Harun, 2020; Zakariyah \& Hamid, 2020).

Several studies have been carried out previously, including Triwardhani's research (2020) that the teacher's communication strategy in involving parents is to build parental commitment from the 
start and communication is carried out continuously; Sun'iyah (2020) that the synergy of the roles of parents and teachers can be done with good communication patterns. Teacher innovation and creativity in applying quality online learning media are proactive steps to establish communication with parents. Integrated parental supervision with teacher directions in dealing with children's interactions in cyberspace; Ardiawan (2020) that the strategy that can be used for solutions to improve teacher communication with parents in supporting online learning is by using PMP strategies, namely understanding, educating, and supervising. This strategy is elaborated into communication between parents and teachers in supporting the online learning process; Khadijah (2020), Risdoyok (2021), Cahyani (2021), Limbong (2020), Dewi (2020), Irwanto (2020), Chayati (2021), Nazarudin (2018) and other research. What distinguishes it from previous research is Islamic Religious Education teachers' and parents' communication patterns, supporting factors, and factors that hinder communication.

\section{METHOD}

The research method used is qualitative with a phenomenological approach. The informants in this study were 3 teachers and 3 parents of 8th-grade students using the purposive sampling technique. Data collection was carried out by in-depth interviews with structured interview techniques conducted through Video Calls for 20 minutes in 3 meetings. A tool used to organize data through Thematic Analysis. Then the data were analyzed by the Colaizzi method, namely by validating the data by returning the research results to the informants to validate the interview data.

\section{FINDINGS AND DISCUSSION}

\section{Implementation of Islamic Religious Education Learning}

Islamic Religious Education learning carried out by teachers starts from planning, implementation, and evaluation. The first step was taken by the teacher in lesson planning, as stated by Mr. P below:

"Before carrying out learning, I prepare for learning administration one of the Learning Implementation Plans (RPP). The RPP used is adjusted to the conditions of the Covid-19 Pandemic with 1 sheet of Online RPP. Furthermore, the selection of applications used for learning includes Google Classroom, Google Meet, and WhatsApp."

Next, Ms. YI said:

"The first thing I did was prepare learning administration including Syllabus and Learning Implementation Plans (RPP). The RPP that I compiled uses the online version due to Covid-19. The application used is WhatsApp. Meanwhile, to assess using Google Forms."

Ms. H said:

"In planning, what I do is prepare learning tools starting from the Annual Program to the Learning Implementation Plan. The RPP comprises subject identities, core competencies, learning activities, and learning evaluations. Following the directions from the school, teachers are asked to use applications for online learning. The application that I use is WhatsApp because almost all students use it."

The results of the interview above show that before carrying out the lesson, the teacher plans the lesson by preparing the learning administration. The activities carried out include 1) preparing a lesson plan (RPP) and 2) selecting an online learning application. The RPP that was prepared was adjusted to the conditions of the Covid-19 Pandemic, namely using the Online RPP. The RPP includes learning activities by adjusting the learning applications used. Next, for the assessment using Google Form.

The second step taken by Islamic Religious Education teachers is the implementation of learning. The implementation of learning is carried out online and refers to the Learning Implementation Plan as stated by Mr. P below: 
"The allocation of learning time is 60 minutes for 1 meeting. Taking advantage of this time, you can ask students to fill in attendance in the Classroom; the teacher asks students to read the material in the textbook; teachers conduct face-to-face meetings through Google Meet to explain learning materials and discuss, and ask students to do assignments. Before learning activities, I send the learning stages in the class WhatsApp group. On another occasion, I explain learning materials in videos uploaded on YouTube. Student assignments submitted via Classroom.”

Ms. YI said:

"For online learning, I use WhatsApp, and the steps are to make attendance via messages and video calls one by one; explain the material through video recordings, picture notes, and links; students are asked to respond to voice recordings (voice); when doing assessments and giving assignments, the teacher asks students to do assignments in the book. Assignment submission by sending pictures in WhatsApp group."

Ms. H said:

"The stages of learning activities through WhatsApp are making attendance by sending a list of student attendance, explaining the material via video, asking students to ask questions if they don't understand the material, then giving assignments to students.”

The interview results above show that online learning is implemented using several applications, including Google Classroom, Google Meet, and WhatsApp. The application includes preliminary, core, and closing activities and assessments. The introductory activity begins with attendance and literacy. In this activity, the teacher delivers material and discusses. In the closing activity, the teacher asks students to do assignments and then be assessed.

The use of applications such as WhatsApp, Google Meet, and Google Classroom has several advantages in online learning, as stated by Mr. P below:

"I use Classroom in religious learning because of the many advantages of the application such as making attendance, making quizzes, sending material in video or pdfform, being able to make video calls, make assessments, and others."

Ms. YI said:

"The advantage of using WhatsApp is because this application is used daily, so it is straightforward to use. On the other hand, students and parents almost all use WhatsApp to communicate. Through WhatsApp, I can send materials, videos, voice messages, and pictures."

The results of the interview above show that teachers' use of the Google Classroom, WhatsApp, and Google Meet applications is due to the advantages of each of these applications. One of the considerations is the ease and competence of teachers in information technology.

\section{Teacher and Parents Communication Pattern}

Communication between teachers and parents during the Covid-19 pandemic is essential for the success of students in learning, as stated by Mr. P below:

"During this Covid-19 period, communication with parents is often done to monitor student learning at home. I ask parents to monitor often and accompany their children while studying and check assignments from the teacher. Apart from parents, I also report with the guardian to remind the students."

Ms. YI said:

"Communication with parents is essential because it is to help teachers so that their children follow learning. Communication that I do at least in 1 month 2 times communicate with parents of students, especially students studying from home, so it requires cooperation with parents. If it is not done, it could be that students are less effective in learning." 
Next Ms H said:

"During Covid-19, communication with parents of students has increased because children are not studying at school, so teachers need to work with parents to ensure that they receive learning materials and that students participate in learning. For effective communication, I created a WhatsApp group to provide information."

The interview results above show that teacher communication with parents has increased more than usual due to Covid-19, which requires students to study from home. With this condition, the teacher must work with parents to ensure students learn well and receive learning from the teacher. Teachers often remind parents to monitor their children at home to provide students learn continually.

The communication made by the teacher is related to learning and other supporting information as stated by Mr. P below:

"Communication that I do with parents regarding changes to the schedule of subjects, reminding parents to comply with $3 M$, student discipline, wearing school uniforms, and assignments."

Ms. YI said:

"Communication with parents that I often do include problems that occur to students, for example, often not being absent and participating in online learning and information from schools such as lesson schedules, vaccine schedules, and others.”

Ms. H said:

"Often I communicate with parents related to the problems faced by students including not taking lessons, not doing assignments, and scores below the minimum completeness criteria."

The interviews above show that communication between teachers and parents is carried out because of the information to be conveyed to parents, both general learning information and internal problems for students. The available information usually communicated includes subject schedules, exam schedules, vaccine schedules, competitions, and other information. Meanwhile, the student's personality is typically related to problems such as not going to school, not doing assignments, and students' grades being below the standard.

The statement conveyed by the teacher was also given by the parents of Mrs. RI as follows:

"The teacher contacted me several times via WhatsApp because my son often did not take religious lessons. The teacher reminded me to monitor her child to keep studying at home. After that, I remind my child to study."

Likewise, Mrs. M said:

"About a week ago, I got a call from a religion teacher because my son had not submitted his religious assignment. At other times, the teacher often informs the group to comply with the Health protocol and vaccination schedule."

Next, Ms. D said:

"We parents also often ask the teacher about the child's progress and information that we don't understand, such as the lesson schedule that frequently changes holiday dates and vaccination information from the school. The media that I use to communicate are telephone and WhatsApp."

Based on the interviews above, communication between religious teachers and parents relates to school information and their children's learning development. Communication is carried out to support student learning during the Covid-19 Pandemic. The good thing about this communication is that there is a change in student behavior, such as being disciplined and diligent in doing the assignments from the teacher. The communication carried out by teachers is very effective using telephone assistance and short message applications because they only need credit and internet 
packages, they can communicate without the need to visit or call parents to school, and of course this is an effort to support government instructions to break the chain of the spread of Covid-19.

Thus, the results of this interview indicate that the pattern of communication between religious teachers and parents is a secondary or two-way communication pattern. Harmonious communication between teachers and parents is essential to support student success in learning and achieving the school's vision. During this Covid-19 pandemic, teachers must always communicate with parents because teachers cannot directly monitor students at home, so parental help to supervise their children's learning is essential. However, it is also possible for religious teachers to communicate with homeroom teachers, counseling guidance teachers, and school principals if the problems that occur to students cannot be resolved.

\section{Supporting and Inhibiting Factors}

Communication between religious teachers and parents is well established because of the supporting factors, but several factors may hinder this communication, as stated by Mr. P below:

"Factors that support good communication with parents include awareness of responsibility as a teacher. I want my students to take good lessons with good results too. In addition, it is greatly helped by short messaging applications such as WhatsApp to easily communicate with parents through messages, voice calls, and video calls. Furthermore, some parents communicate first when their children have problems learning without the teacher providing information. The thing that hinders communication is that parents don't respond and tend not to care when the teacher wants to convey the problems facing their children".

Ms. YI said:

"In communicating with my parents, I use the phone and the WhatsApp application because it is easy to use without the need to meet in person. Meet with parents if student problems can be resolved. In addition, it is my duty as a teacher to always communicate with parents, especially in the Covid-19 era, because students study from home and need to be supervised. The inhibiting factor is that parents do not care about their children's learning, parents are busy working”.

Ms. H said:

"Communication between teachers and parents occurs because of the teacher's awareness, and I was a teacher need to convey the development of student learning to their parents, especially when children encounter obstacles in learning. In addition, some parents often ask their children about attendance and task completion. Some of my students come from families whose parents have separated, so it is difficult to communicate".

The interviews above show that communication between religious teachers and students' parents is harmonious because it is supported by several factors, including the awareness of teachers and parents of their responsibilities. Teachers have responsibilities to their students, namely guiding, directing, facilitating, educating, and other roles. The teacher carries out this role to maximize the potential in students so that learning objectives can be achieved, including knowledge and character.

Parents' awareness of their responsibilities is one of the supporting factors. Parents have a responsibility towards their children by ensuring that children follow the learning that the school has programmed. Parents can help the school by supervising children who study at home and constantly communicating with teachers, especially when their children encounter obstacles in learning. If necessary, parents take the time to accompany their children to study, especially during the Covid-19 pandemic, parents, and teachers must work together. 
During the Covid-19 pandemic, communication between religious teachers and parents went well because of the support from communication media such as telephones and short message applications such as WhatsApp. Teachers can communicate with parents anytime and anywhere by voice calls, video calls, messages, and more with this media. In addition, the media is very easy to use.

Communication does not always go well. There are some obstacles, including the attitude of teachers who don't care enough to only focus on teaching to release responsibilities, there are some parents who don't care about their children's learning and don't even know the problems their children are facing, and family factors parents being separated also makes it difficult for teachers to communicate.

\section{Implementation of Islamic Religious Education Learning}

Islamic Religious Education learning is carried out online due to the Covid-19 Pandemic, which impacts face-to-face learning directly to online learning. Management of learning by teachers starts from planning, implementation, and evaluation. The management that has been carried out follows the management function, which starts with planning, organizing, implementing, and evaluating in creating active students (Nasbi, 2017). One of the things done in the planning stage is the preparation of learning administration, such as the Learning Implementation Plan. Learning Implementation Plans that are prepared to adapt to the conditions of the Covid-19 Pandemic.

The Learning Implementation Plan is prepared based on the existing school conditions, namely the Online Learning Implementation Plan. This is due to the state of schools that do not organize face-to-face learning. The construction of an online Learning Implementation Plan with a face-toface Learning Implementation Plan is not much different. An online Learning Implementation Plan is an online learning implementation plan prepared according to basic competencies. The Learning Implementation Plan becomes the teacher's guide in carrying out the learning process. The teacher's Learning Implementation Plan uses various learning application features such as Whatsapp and Telegram (Rasidi et al., 2021).

The Google Classroom (GCR) application is the primary choice of media in implementing online learning because it is considered quite effective. Teachers can meet face to face and communicate as usual, even though they are virtual. Thus, there will be direct interaction. How to use it is easy. Meanwhile, the WhatsApp application is an alternative if there are technical problems in using GCR and media outside of learning (Astuty \& Suharto, 2021). Some teachers use other alternative media such as Google Meet and Zoom (Zaini et al., 2021).

PAI learning in schools encountered several obstacles, including the internet network's stability, limited internet quota of students, lack of student discipline, lack of attention from parents of students, and student motivation. In online learning, the stability of the internet network is very influential. If the weather is not good, it will cause internet network disruption. Things like this are also a weakness in conducting long-distance (in-network) deployments. In addition to relying on the stability of the internet network, online learning is also very dependent on the availability of internet quotas owned by teachers and students. The various economic conditions of students cause the availability of different quotas for students. Students from less affluent families will have considerable obstacles in online learning. This of course, will affect the learning process. This finding reinforces the research of Jamaluddin (2020), Rigianti (2020), and Firdaus (2020)) that an unstable internet network and limited quota are two significant aspects that interfere with the online learning process.

Learning online (on a network) will make students focus during the online learning process distracted with other activities. For example, they are studying while chatting with other students, watching movies, studying accompanied by noise from the situation around the house, etc. In addition to the disturbed focus of students, other things that cause a lack of student motivation in online learning are the lack of supervision from parents at home and the lack of understanding of 
students about the material given by the teacher. This finding strengthens Anugrahana's (2020) research that the weakness in online learning is the lack of maximum student involvement. The student involvement in question is the involvement of students in fully participating in online learning from the beginning of learning to the end of learning.

\section{Communication Pattern of Teacher and Parents}

The communication pattern between PAI teachers and parents is carried out with a secondary two-way or reciprocal communication pattern (two-way traffic communication). During this Covid19 pandemic, communication is carried out using cellphones and WhatsApp. Communication between teachers and parents is related to several things, including student discipline, assignments, achievements, and learning information. During the Covid-19 pandemic, some students did not fill in attendance and did not even attend lessons for a few days, so the teacher communicated with parents to confirm the reason for not attending school. Furthermore, if the student does not do the assignment, the PAI teacher contacts the parents to convey the problem. In addition, the learning schedule during the Covid-19 pandemic often changes according to conditions.

Communication between teachers and parents often occurs because of learning problems experienced by their children. The intensity of the contact is almost every week because of the many issues. This is caused by the lack of parental attention at home and student learning motivation due to direct supervision from parents and teachers. Before the Covid-19 pandemic, students studying at school were supervised by teachers, especially during learning hours. However, in contrast to current conditions, teacher-to-person communication needs to increase collaboration and intensity because students learn from home. PAI teachers in communicating with parents experienced several obstacles, including students' parents being busy working, not caring about their parents, and parents not having handphones.

Pang and Watkins stated that communication between parents and teachers is usually in the form of exchanging information and ideas about the development and development of children at school and at home (Symeou et al., 2012). Parents get information about the things their children do and reach, while teachers get data about their students' activities while playing and studying at home. Henderson and Bella argue that parental involvement in the learning process can improve children's grades, children's attendance in learning at school, foster good attitudes and behavior in children and increase graduation rates. The results of research corroborate this by Dixon (1992), Eccles \& Harold (1993), Henderson \& Bella (1994), and Jeynes (2007), which show that when parents and teachers have a good relationship/cooperation, academic achievement and Children's social skills will increase (McCarthy et al., 2011). Children's communication with parents and teachers in their respective environments positively develops children's creative thinking skills (Suryadi, 2010).

Whether we realize it or not, communication between parents and teachers starts from the first day parents set foot in school. The first impression significantly affects the parents' perspective on the school. The smile and friendliness shown by the teacher, the school atmosphere, and the school's cleanliness substantially affect parents' views. A friendly school environment shows how much the school appreciates the importance of communicating with parents (Pusitaningtyas, 2017).

According to Berger in Graham-Clay, communication can involve one or two-way exchange of information. One-way communication occurs when the teacher provides information to parents about events, activities, or progress achieved by children through various sources such as report cards, link books, and school websites-called two-way communication if there is an interactive dialogue between teachers and parents. For example, telephone conversations, home visits, parent and teacher meetings, and school activities require other parents' presence. Effective dialogue between teachers and parents will foster trust, mutuality, and respect between the two. A teacher must combine these two ways of communication in providing information to parents (Graham-Clay, 2005). 
The communication media used by teachers and parents are WhatsApp, short message applications, and handphones. The use of the WhatsApp application is easy to use. Many tools are available, such as video calls, chats, calls, sending documents, images, videos, audio, and others. If communication via WhatsApp cannot be carried out, the teacher uses a cellphone. This media effectively reaches parents and students at home and breaks the chain of the spread of Covid-19.

In communicating, teachers and parents should exchange information directly at school or exchange information through mobile communication tools. With good communication and mutual openness between the two, the learning process will run optimally, especially in the current conditions that require the learning process to be carried out online (online). Good communication between teachers and parents is needed (Fatmawati, 2020).

\section{Supporting and Inhibiting Factors}

Several factors, namely support communication between PAI teachers and parents:

a) Awareness of responsibility as a teacher

Teachers have duties and responsibilities in carrying out their profession. One of his responsibilities is to guide and educate students. The teacher will communicate with parents if students have problems that hinder learning achievement. It aims to find solutions to the issues faced, and in the future, it will not happen again and become the attention of parents. Teachers are professional educators with the main task of educating, teaching, guiding, directing, training, assessing, and evaluating students in early childhood education through formal education, primary education, and secondary education (Penyusun, 2005).

b) Awareness of responsibility as a parent

This awareness is essential for the success of their children's learning. Parents do not only fully release to the school related to their children's learning, but parents have to play the primary role in ensuring their children get learning and participate in learning at school.

Parents will communicate with teachers about problems and their children's learning development, such as discipline problems, achievement, and others. Likewise with teachers, when teachers report their students' progress to parents, parents immediately explain their children's condition and follow up on the problems they face by making improvements. There are some parents without being contacted by the teacher. They ask about the progress of their children's learning at school.

The family is the primary and first institution for the initial process of children's education to develop a child's potential towards creating a positive and good personality. Parents (father and mother) have a great responsibility in educating children in the family. The functions and roles of parents are not only to meet the physical needs of children in the form of food and drink, clothing, shelter but also the responsibility of parents is much more important than that is to give attention, guidance, direction, motivation, and education, as well as planting mark (Jailani, 2014).

c) Easy and convenient communication media

Communication between teachers and parents is helped by easy and convenient communication media. Currently, almost all parents and teachers have handphones and smartphones. Both of this help communicate quickly without taking a lot of time. Teachers and parents have cellphones, while smartphones use short messaging applications like WhatsApp and Telegram.

WhatsApp is constructive in communicating activities in distance learning during current conditions. WhatsApp media has several advantages, namely easy, practical, fast, saving internet data, and can be accessed only by cellphone, has various features that can be used to support communication such as New Group, New Broadcast, WhatSApp Web, Starred Messages and Settings with the help of internet service (Sidiq, 2019). 
While the factors that hinder the communication of teachers and parents are:

a) Lack of concern for teachers

The teacher's indifference to the problems students face will hurt learning achievement. Communication cannot occur if the teacher is less concerned. Some students must have obstacles in their learning that need solutions with cooperation between teachers and parents.

b) Lack of parental care

Lack of parental concern for their child's learning will also hurt learning achievement. There are still parents who completely surrender their children's learning to school, and this thinking is not valid. Children's success in learning requires support from all components that work together. During the Covid-19 pandemic, parents often neglect to ask their children for online learning. Teachers forget to check their children's smartphones to make sure they are following the lessons and assignments from the teacher because they are busy making a living.

c) The condition of the student's family is a mess (broken home)

Teachers often have difficulty communicating with parents of students whose households are in trouble (broken home) due to divorce. When the teacher tries to speak, the students' parents are indifferent by blaming each other's husband or wife for their child's condition. In some cases, teacher communication is done with the students' aunts or grandmothers, not their parents.

\section{CONCLUSION}

This study concludes that the communication pattern used by PAI teachers and parents is a secondary or two-way, or reciprocal communication pattern (two-way traffic communication). In communicating, there are supporting factors, including awareness of responsibilities as teachers and parents and easy and convenient communication media. Furthermore, the lack of concern for teachers and parents and students' broken homes hinder communication. Harmonious communication between teachers and parents supports student and teacher learning success. Thus, the communication needs to be carried out intensely and continuously and involves other school members such as the principal, homeroom teacher, and students.

\section{REFERENCES}

Anugrahana, A. (2020). Hambatan, solusi dan harapan: pembelajaran daring selama masa pandemi covid-19 oleh guru sekolah dasar. Scholaria: Jurnal Pendidikan Dan Kebudayaan, 10(3), 282289.

Ardiawan, I. K. N., \& Heriawan, I. G. T. (2020). Pentingnya Komunikasi Guru Dan Orang Tua Serta Strategi PMP Dalam Mendukung Pembelajaran Daring. Danapati: Jurnal Ilmu Komunikasi, 1(1), 95-105.

Ashsiddiqi, H. (2012). Kompetensi sosial guru dalam pembelajaran dan pengembangannya. Ta'dib: Jurnal Pendidikan Islam, 17(01), 61-71.

Astuti, I. Y., \& Harun, H. (2020). Tantangan Guru dan Orang Tua dalam Kegiatan Belajar Dari Rumah Anak Usia Dini pada Masa Pandemi Covid-19. Jurnal Obsesi : Jurnal Pendidikan Anak Usia Dini, 5(2), 1454-1463. https://doi.org/10.31004/obsesi.v5i2.808

Astuty, W., \& Suharto, A. W. B. (2021). Desain Perencanaan Pelaksanaan Pembelajaran Pendidikan Agama Islam Daring dengan Kurikulum Darurat. Jurnal Penelitian Pendidikan Islam, 9(1), 8196.

Cahyani, A. D., Yulianingsih, W., \& Roesminingsih, M. V. (2021). Sinergi antara Orang Tua dan Pendidik dalam Pendampingan Belajar Anak selama Pandemi Covid-19. Jurnal Obsesi: Jurnal Pendidikan Anak Usia Dini, 6(2), 1054-1069.

Chayati, N. (2021). Komunikasi Guru dan Orang Tua Siswa dalam Mengoptimalkan Pembelajaran Pada Masa Pandemi di SDI Al-Ittihad Tukum Tekung Lumajang. Rabbani: Jurnal Pendidikan Agama Islam, 2(2), 113-139. 
Dewi, M. (2020). Analisis Kerja Sama Guru dengan Orang Tua dalam Pembelajaran Online di Era Covid 19 di MI Azizan Palembang. Jurnal Edukasi Madrasah Ibtidaiyah, 2 (2), 54, 64.

Dewi, W. A. F. (2020). Dampak COVID-19 terhadap Implementasi Pembelajaran Daring di Sekolah Dasar. Edukatif: Jurnal Ilmu Pendidikan, 2(1), 55-61.

Fatmawati, E. (2020). Kerjasama Orang Tua Dan Guru Dalam Meningkatkan Motivasi Belajar Peserta Didik. IBTIDA', 1(2), 135-150.

Firdaus, F. (2020). Implementasi Dan Hambatan Pada Pembelajaran Daring Di Masa Pandemi Covid 19. Utile: Jurnal Kependidikan, 6(2), 220-225.

Graham-Clay, S. (2005). Communicating with parents: Strategies for teachers. School Community Journal, 15(1), 117-129.

Irwanto, M. S. H. (2020). Implementasi Kolaborasi Orang Tua dan Guru Dalam Pelaksanaan Pembelajaran Daring Pada PAUD. JIEES: Journal of Islamic Education at Elementary School, 1(1), 17-24.

Jailani, M. S. (2014). Teori pendidikan keluarga dan tanggung jawab orang tua dalam pendidikan anak usia dini. Nadwa: Jurnal Pendidikan Islam, 8(2), 245-260.

Jamaluddin, D., Ratnasih, T., Gunawan, H., \& Paujiah, E. (2020). Pembelajaran daring masa pandemik Covid-19 pada calon guru: hambatan, solusi dan proyeksi. LP2M.

Khadijah, K. (2020). Pola kerja sama guru dan orangtua mengelola bermain AUD Selama masa pandemi COVID-19. Kumara Cendekia, 8(2), 154-170.

Kurniawati, A. (2013). Pola Komunikasi Guru dan Orang Tua Dalam Pembinaan Karakter Murid di Taman Kanak-kanak El-Fikri Yayasan Kahfi Tangerang Selatan.

Limbong, M., Ali, S., Rabbani, R., \& Syafitri, E. (2020). Pola Interaksi Guru Dan Orang Tua Dalam Mengendalikan Emosional Siswa Selama Pembelajaran Daring Di Mts Islamiyah Medan. THORIQOTUNA: Jurnal Pendidikan Islam, 3(1), 44-55.

Maryani, K. (2020). Penilaian dan Pelaporan Perkembangan Anak Saat Pembelajaran di Rumah di Masa Pendemi Covid-19. Murhum: Jurnal Pendidikan Anak Usia Dini, 41-52.

Masdul, M. R. (2018). Komunikasi pembelajaran. IQRA Jurnal Ilmu Kependidikan Dan Keislaman, 13(2), 1-9.

McCarthy, P. J., Brennan, L., \& Vecchiarello, K. (2011). Parent-school communication in the inclusive classroom: A comprehensive model of collaboration in education. International Journal of Humanities and Social Science, 1(15), 55-60.

Muspiroh, N. (2016). Peran kompetensi sosial guru dalam menciptakan efektifitas pembelajaran. Edueksos: Jurnal Pendidikan Sosial \& Ekonomi, 4(2).

Nasbi, I. (2017). Manajemen kurikulum: Sebuah kajian teoritis. Idaarah: Jurnal Manajemen Pendidikan, 1(2).

Nazarudin, M. (2018). Pola Kerjasama Guru dan Orang Tua dalam Meningkatkan Mutu Pendidikan di MIN 2 Kota Palembang. Intizar, 24(2), 211-218.

Penyusun, T. (2005). Undang-Undang Guru dan Dosen Nomor 14 Tahun 2005.

Pusitaningtyas, A. (2017). Pengaruh Komunikasi Orang Tua Dan Guru Terhadap Kreativitas Siswa. Proceedings of the ICECRS, 1(1).

Rasidi, M. A., Hikmatullah, N., \& Sobry, M. (2021). Hambatan guru dalam pembelajaran daring: Studi kasus di kelas V MIN 2 Kota Mataram. Jurnal Ilmiah Pendidikan Dasar, 8(2), 159-174.

Rigianti, H. A. (2020). Kendala Pembelajaran Daring Guru Sekolah Dasar di Banjarnegara. Elementary School: Jurnal Pendidikan Dan Pembelajaran Ke-SD-An, 7(2).

Risdoyok, R., \& Aprison, W. (2021). Kerjasama guru pai dan orang tua dalam menghadapi pembelajaran selama covid-19. EDUKATIF: Jurnal Ilmu Pendidikan, 3(5), 2319-2335.

Sidiq, R. (2019). Pemanfaatan Whatsapp Group dalam Pengimplementasian Nilai-Nilai Karakter Pancasila Pada Era Disrupsi. Puteri Hijau: Jurnal Pendidikan Sejarah, 4(2), 145-154.

Sihotang, N. (2014). Eksplorasi komunikasi dakwah interpersonal dalam al-Quran surat Luqman. HIKMAH: Jurnal Ilmu Dakwah Dan Komunikasi Islam, 8(1), 107-114.

Sopian, A. (2016). Tugas, peran, dan fungsi guru dalam pendidikan. Raudhah Proud To Be Professionals: Jurnal Tarbiyah Islamiyah, 1(1), 88-97.

Sun'iyah, S. L. (2020). Sinergi Peran Guru Dan Orang Tua Dalam Mewujudkan Keberhasilan Pembelajaran Pai Tingkat Pendidikan Dasar Di Era Pandemi Covid-19. DAR EL-ILMI: Jurnal Studi Keagamaan, Pendidikan Dan Humaniora, 7(2), 1-16.

Suryadi, E. (2010). Model Komunikasi Efektif bagi Perkembangan Kemampuan Berpikir Kreatif Anak. Jurnal Ilmu Komunikasi Terakreditasi, 8(3), 263-279. 
Syatriadin, S. (2018). Pembelajaran Sebagai Media Komunikasi. NUANSA, 6(2), 23-32.

Symeou, L., Roussounidou, E., \& Michaelides, M. (2012). "I Feel Much More Confident Now to Talk With Parents": An Evaluation of In-Service Training on Teacher-Parent Communication. School Community Journal, 22(1).

Tatang, S. (2016). Dinamika Komunikasi. Pustaka Setia.

Trisno. (2010). Guru agama perspektif hasan Langgulung dan undang-undang no 14 tahun 2005 tentang guru dan dosen.

Triwardhani, I. J., Trigartanti, W., Rachmawati, I., \& Putra, R. P. (2020). Strategi Guru dalam membangun komunikasi dengan Orang Tua Siswa di Sekolah. Jurnal Kajian Komunikasi, 8(1), 99-113.

Zaini, H., Hadi, A., Sofyan, F. A., \& Hamzah, A. (2021). Covid-19 and Islamic Education in School: Searching for Alternative Learning Media. Webology, 18(1).

Zakariyah, A., \& Hamid, A. (2020). Kolaborasi Peran Orang Tua dan Guru dalam Pembelajaran Pendidikan Agama Islam Berbasis Online di Rumah. Intizar, 26(1), 17-26. 